Acta Veterinaria (Beograd), Vol. 63, No. 5-6, 569-579, 2013.

\title{
SEROEPIZOOTIOLOGICAL-EPIDEMIOLOGICAL INVESTIGATION AND MAPPING OF WEST NILE INFECTION IN THE REPUBLIC OF SERBIA
}

\author{
ĐURIČIĆ BOSILJKA*, VASIĆ ANA*, ROGOŽARSKI D**, VOJINOVIĆ DRAGICA***, \\ ELEZOVIĆ RADOVANOVIĆ MILICA*, MANIĆ MARIJA*, MARIĆ J*, PROKIĆ NATASA*, \\ ILIĆ ŽIVKA ${ }^{* * *}$, NOVOTNY ${ }^{* * * *}$, GLIGIĆ ANA ${ }^{* * * * *}$ \\ *University of Belgrade, Faculty of Veterinary Medicine, Belgrade, Serbia \\ **Veterinary Specialistic Institute, Požarevac, Serbia \\ ${ }^{* * \star}$ Scientific Veterinary Institute of Serbia, Beograd, Serbia \\ ****University of Veterinary Medicine, Wien, Austria \\ *****Institute for Virology, Vaccines and Sera "Torlak", Belgrade,Serbia
}

(Received 15 ${ }^{\text {th }}$ May 2013)

The disease caused by the West Nile virus (WNV) has been known since 1937 when it was described for the first time in Uganda. After spreading to Europe and the Middle East, the disease has changed its primary location. Today WN infection is a significant health problem in the world. As a result of the current epizootiological and epidemiological situation in Europe studies on the occurrence of WND were introduced in Serbia, also. The investigation on the presence of WNV antibodies was intensified in the period from 2008 to 2012. In this period a total of 3618 serum samples were tested from 18 localities (2736 animal sera from 8 different species and 882 human sera samples). The method applied was gel immunodiffusion and the representative samples were confirmed by the plaque reduction test (PRNT-90). Out of the total number of samples WNV antibodies were present in $3.97 \%$ horses, $0.93 \%$ dogs, $0.31 \%$ poultry and $1.36 \%$ man. In one horse serum sample there was a positive reaction with a positive control serum, thus indicating the presence of WNV antigen.

The results have confirmed that WNV antibodies are present in 9 out of 18 tested locations in the Republic of Serbia. The percentage of seropositive samples varies from $0.42 \%$ in Pozarevac (horses and humans) up to $6.45 \%$ in Novi Pazar (dogs). Out of the investigated species the highest seropositivity was recorded in horses (3.97\%), and lowest in poultry (0.31\%). WNV is present and widespread in the Republic of Serbia, thus enabling distribution mapping.

Key words: Agar gel immunodiffusion test, mapping, plaque neutralization test, Republic of Serbia, seroprevalence, West Nile virus 


\section{INTRODUCTION}

The disease caused by the West Nile virus (WNV) was recorded for the first time in 1937 in the West Nile region in Uganda (Smithburn et al., 1940). In Europe it was first reported in Israel in 1951. WNV illness appears sporadically, however the largest epidemics was recorded in Israel $(1951-1954,1957)$ and in the Republic of South Africa (1974). With the first appearance of WNV in the USA in 1999, WNV became the first Flavivirus from the "old world" which spread to the "new world" (Asnis et al., 2000; Nash et al., 2001).

In the recent years in Europe WNV is becoming more common, as well as the number of infected people. During the epidemics in Romania in 1996 WNV was confirmed in 393 individuals (Cernescu et al., 1997), and in Russia in 1999 where were reported 942 cases (Platonov et al., 2001).

Countries which reported cases of WNV in humans, birds and horses are: Romania (1996), Morocco (1996 and 2003), Tunisia (1997), Italy (1998 and 2008), Russia (1999), USA (1999), Israel (1999), France (2000 and 2004), Canada (2002), Hungary (1999, 2001 and 2008), (Barzon et al., 2009; Krisztalovitcs et al., 2008; Hayes et al., 2005; Campbell et al., 2002). During July and August 2010 there was a large WN disease epidemic in Northern Greece with more than 100 registered cases and 34 lethal outcomes. WNV infection was confirmed by serology, virology and molecular biology tests. During the last years increased mortality of susceptible animals, as well as an increased number of infected men were recorded (Papa et al., 2010).

West Nile Virus belongs to the Flaviviridae family, genus Flavivirus. In the natural environment the virus circulates between the vectors (mosquitoes Culex spp. and Aedes spp.) and the hosts i.e. birds, horses, humans and other vertebrates (Hayes et al., 2005; Campbell et al., 2002). With global climatic changes and increased global temperature the areal of the vectors which transmit WNV is increasing. Besides, increased global temperature results in a longer period of activity of the WNV vectors and mild winters favor a longer and easier circulation of WNV vectors in nature.

All WNV isolates are divided into two major lineages. The origin of lineage $1 \mathrm{WNV}$ is registered in North America, North Africa, Europe and Australia. The origin of lineage 2 is considered to be endemic and related to South Africa and Madagascar (Burt et al., 2002; Lanciotti et al., 1999). Up to the publication of studies carried out in South Africa (Burt et al., 2002) it was considered that lineage 2 WNV isolates cause mild clinical infections with a low virulence of the virus. The isolation of lineage 2 WNV in Hungary in a gawshawk (Accipiter gentilis) who died, due to encephalitis has confirmed that lineage 2 WNV can be transmitted by migrating birds from Africa to Europe and it can cause severe clinical symptoms in susceptible species (Bakonyi et al., 2006).

The presence of WNV antibodies in the Republic of Serbia was recorded after serological testing on humans in 1972 when Bordjoski et al., published the 
first data on the presence on WNV antibodies in different regions of Serbia. The presence of hemagglutinating inhibitory antibodies in the 1726 tested sera samples has shown different results for different regions in Serbia. It was proven that $0 \%$ tested serum samples had positive results in the region of Sandžak and $19.4 \%$ were positive in the region of Western Serbia. Bearing in mind the epidemiological data it is clear that WNV is circulating in Serbia for decades. Hrnjakovic et al. (2009) identified WNV antibodies in 2 cases of 27 hospitalized patients with diagnosed meningoencephalitis and in 2 out of 89 blood donors. Preliminary results of studies on the presence of WNV antibodies in different animal species and men in the region of Obedska Bara (Serbia) were published by Djuricic et al. (2009). Kuljic-Kapuljica et al. (2009) published their survey results which have shown that $4.76 \%$ out of 105 tested individuals with multiple mosquito bites were seropositive. Lupulovic et al. (2011) recorded $12 \%$ were WNV seropositive out of 349 tested horses. One of the tested horse serum samples also cross reacted with the Usutu virus (Lupulovic et al., 2011).

The geographical position of the Republic of Serbia on the Balkan peninsula is significant and it represents a crossroad of both land and airborne corridors, thus the natural reservates of Serbia are exposed to the migratory routes of birds from Africa to Europe and vice versa. The large number of susceptible animal species and the close contact between vectors, birds, vertebrates, and humans make these areas sensitive to the long-term activity of a large number of pathogens such as WNV. Due to the current epidemiological and epizootiological situation in the neighboring countries, a wider investigation on the presence of WNV antibodies in Serbia has been carried out. Studies on the presence of WNV antibodies have been intensified since 2008 with the aim to determine the presence of WNV antibodies in man and animals in different regions of the Republic of Serbia in the period from 2008 to 2012 and thus carry out mapping of potential natural foci.

\section{MATERIAL AND METHODS}

Sera: during the period from $2008-2012$ a total of 3618 sera samples of different species (1133 horses, 66 donkeys, 1076 dogs, 318 poultry, 102 sheep, 6 goats, 30 cattle, 5 deer) and 882 man were collected and tested. Sampling was done on the following locations: Belgrade, Lazarevac, Loznica, Zasavica, Zajačar, Šabac, Vršac, Subotica, Ub, Novi Sad, and Čačak. Human serum samples (186 samples) used in this study were collected during year 1996 and were stocked at the sera bank of the Institute for Virology, Vaccines and Sera "Torlak". All sera samples were stored at $-18^{\circ} \mathrm{C}$ and before testing were inactivated for $30 \mathrm{~min}$ at $56^{\circ} \mathrm{C}$.

Virus: the WNV (Ital-Milano) - University of Veterinary Medicine, Wien, Austria was multiplied on the rabbit kidney cell line -RK-13.

Positive control sera: were obtained after multiple immunisations (five times) of adult male Swiss albino mice. The mice were immunized twice with a formalin inactivated vaccine and three times with a live virus. Immune mice sera were 
collected 14 days after the last immunisation. All sera samples were stored at a temperature of $-18^{\circ} \mathrm{C}$.

Negative control sera: obtained from adult male Swiss albino mice. All sera samples were stored at $-18^{\circ} \mathrm{C}$.

Preparation of the antigen: the antigen used in the serological study was made from infected cells of tissue culture RK-13, centrifuged at $7000 \mathrm{rpm}$ at +4 ${ }^{\circ} \mathrm{C}$ (sorval RC2-B superseed) for 30 minutes and thereon to the supernatant $6 \%$ polyethileneglycol (PEG Mr 6000) was added. After extraction at $+4{ }^{\circ} \mathrm{C}$ the content was once again centrifuged for 30 minutes at $3000 \mathrm{rpm}$. The sediment was resuspended in borate salty buffer $\mathrm{pH}$ 9.0. The volume of the added buffer was calculated to provide a final antigen concentration 40 times higher. The antigen was stored at $+4^{\circ} \mathrm{C}$ (Čumakov et al., 1969).

Agar gel immunodiffusion test (AGID): 1\% Noble agar solution was made in saline solution and poured into Petri dishes. To perform the test the Ouchterlony method was used (Ouchterlony, 1962, Ouchterlony, 1949). The results were read after 24 and $48 \mathrm{~h}$ of incubation in a humid chamber at $37^{\circ} \mathrm{C}$.

Plaque reduction test for the confirmation of the immunodiffusion test in agar gel: was performed as described by Meister et al. (2008). It was performed on selected test AGID positive sera in the laboratory of the University of Veterinary Medicine in Vienna, Austria.

\section{RESULTS}

Studies on a number of different animal species and man, as well as on different localities resulted in the determination (mapping) of natural foci of WNV in the Repubic of Serbia. At the same time it was important to recognize animal species which have a role in the circulation of WNV in Serbia. Results of investigation on blood serum samples of man and 8 animal species are shown in Table 1.

Table 1. West Nile virus antibodies in human and animmals population discovered by AGID test

\begin{tabular}{|c|c|c|c|}
\hline $\begin{array}{c}\text { Human and } \\
\text { animal sera }\end{array}$ & $\begin{array}{c}\mathrm{N}^{0} \text { of } \\
\text { investigated sera }\end{array}$ & $\begin{array}{c}\mathrm{N}^{0} \text { of } \\
\text { positive sera }\end{array}$ & $\begin{array}{c}\% \text { of } \\
\text { positive sera }\end{array}$ \\
\hline Human & 882 & 12 & 1.36 \\
\hline Donkey & 66 & 0 & 0 \\
\hline Dog & 1076 & 10 & 0.93 \\
\hline Domestic poultry & 318 & 1 & 0.31 \\
\hline Horse & 1133 & 45 & 3.97 \\
\hline Sheep & 102 & 0 & 0 \\
\hline Goat & 6 & 0 & 0 \\
\hline Deer & 5 & 0 & 0 \\
\hline Cattle & 30 & 0 & 0 \\
\hline Total number & 3618 & 68 & 1.88 \\
\hline
\end{tabular}




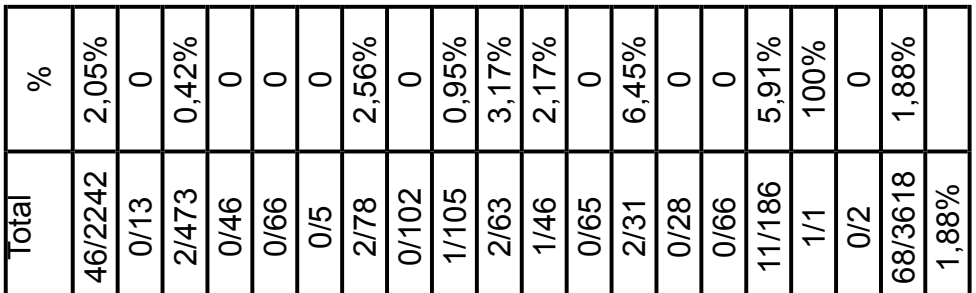

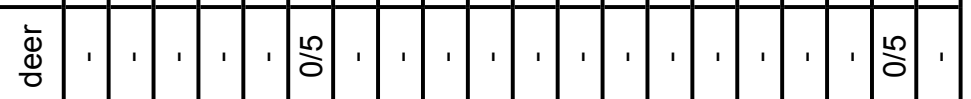

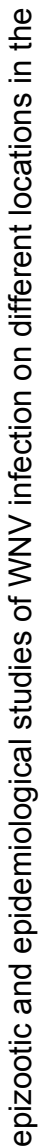

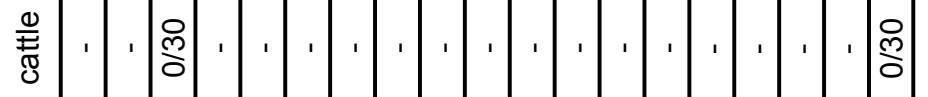

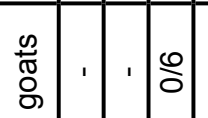

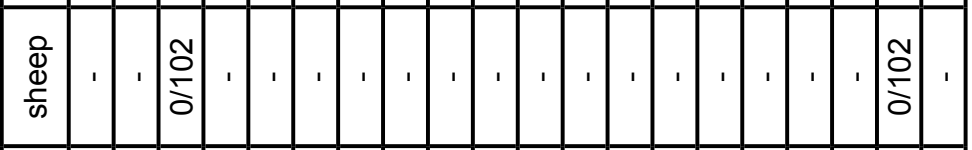

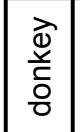

0
0
0

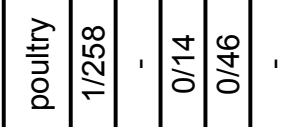

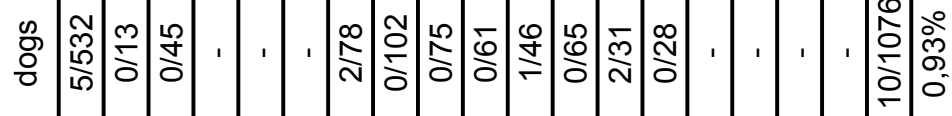

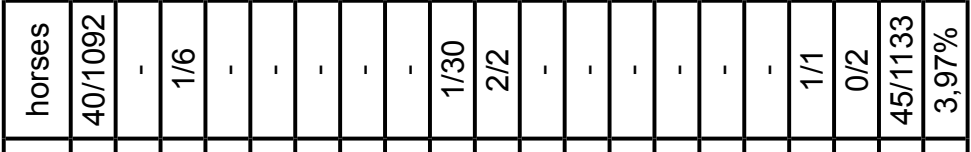

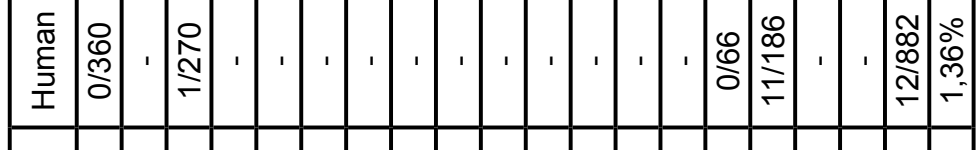

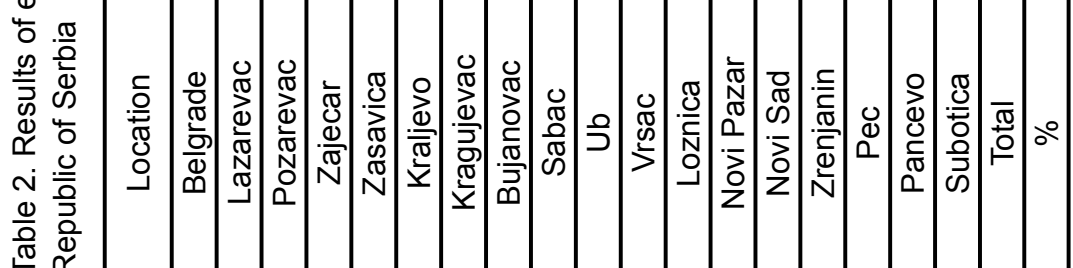


The results given in Table 1 show the highest percentage of seropositive samples to be in horses $(3.97 \%)$, man $(1.36 \%)$, dogs $(0.93)$ and domestic poultry $(0.31 \%)$.

One horse serum sample was positive when reacting with the positive control serum, thus indicating on the presence of WNV antigen. The horse, later on died with signs of inflammation of the central nervous system (encephalitis).

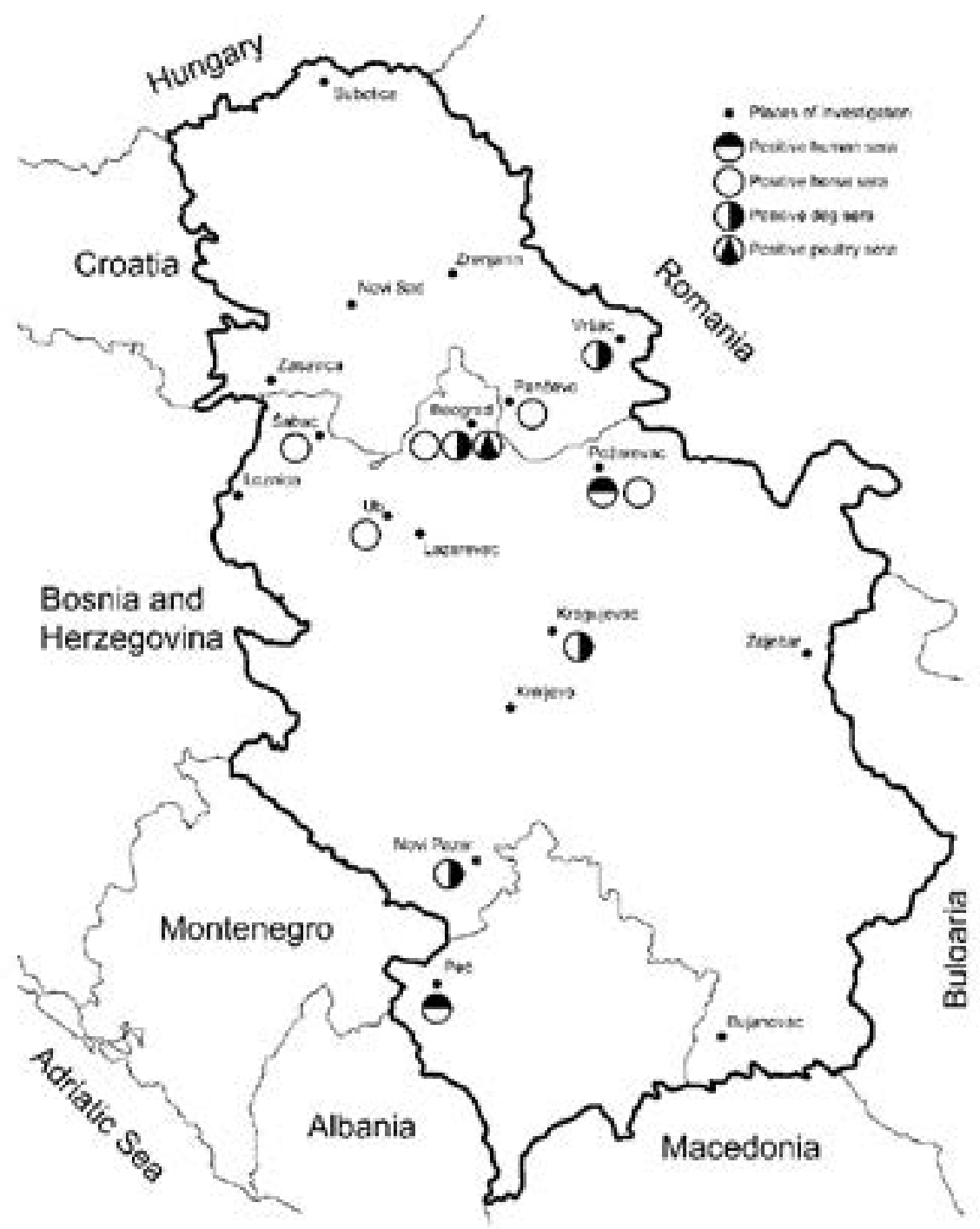

Figure 1. Investigated places of WNV antibody 
Results of seroepizootiological and epidemiological studies on 18 different sites in the Republic of Serbia are shown in Table 2 and Map 1.

Table 2 shows the presence of WNV seropositive samples on 18 investigated sites. The presence of specific antibodies was confirmed in 9 locations. The percentage of positive samples was between $0.31 \%$ and $3.97 \%$, depending on the species studied and from $0.42 \%$ to $6.45 \%$ depending on location. The highest incidence of positive samples for WNV was in horses, with special emphasis on horses from Ub and Pančevo, then Požarevac, Belgrade and Šabac. In dogs, the highest percentage of positive samples was detected in Novi Pazar (6.45\%) then in Kragujevac and Vršac, and in Belgrade was the lowest $(0.93 \%)$. In humans seropositivity was registered in sera from Peć $(5.91 \%)$ and Pozarevac $(0.37 \%)$. Of the other six investigated species seropositivity was detected in domestic poultry in the wider area of Belgrade $(0.38 \%)$. Of all the studied species, domestic poultry had the lowest percentage of WNV positive serum samples $(0.31 \%)$.

Figure 1. shows the results of the prevalence of WNV antibodies in the wider territory of the Republic of Serbia. On the territory of the investigated 18 sites (Belgrade, Lazarevac Loznica Zasavica Zaječar, Zrenjanin, Peć, Novi Pazar, Kraljevo, Kragujevac, Požarevac, Bujanovac, Šabac, Vršac, Subotica, Novi Sad and Pančevo) the highest percentage of seropositive samples was registered in Novi Pazar (6.45\% dogs), then Peć (5.91\% men), Ub (3.17\%, horses), Kragujevac (2.56\% dogs), Vrsac $(2.17 \%$, dogs), Belgrade $(2.05 \%$; horses, dogs, domestic poultry), Šabac $(0.95 \%$ horses $)$ and the lowest percentage was in Požarevac (0.42\%; horses, men).

\section{DISCUSSION}

$\mathrm{WN}$ virus is maintained in nature within the boundaries of the circle between susceptible vertebrate and haematophag arthropods. In the natural foci of this circle which is usually quiet, a dramatic change occurs when humans or domestic animals enter it. These changes are accompanied by epizootic diseases and epidemics. In this way many classical zoonotic diseases have become less exotic, wild and remote and occur in very urban areas (WNV outbreak in New York in 1999.).

WNV epidemic in Romania (1996 and 1997), Greece (2010), and other European countries with a large number of infected people and animals, shows that the virus is actively present and that the disease can occur suddenly. These outbreaks have shown that the virus is present in the Balkans, the Mediterranean region and central Europe (Cernescu et al., 1997; Papa et al., 2010).

The first data on the circulation of WNV in Serbia were published in 1972. (Borđoski et al., 1972) and studies performed from 2008 to 2012 (Table 2) confirmed that WNV is circulating in 9 out of 18 investigated locations in the Republic of Serbia (Map 1). The results showed that the percentage of WNVinfected individuals ranged from $0.42 \%$ in Požarevac (horses and humans) to 
$6.45 \%$ in Novi Pazar (dogs). Of the species tested the highest seropositivity was registered in horses $(3.97 \%)$, and lowest in poultry $(0.31 \%)$.

In correlation with data from Hungary, where WNV was present in humans and several animal species (Bakonyi et al., 2006), as well as in horses and humans, studies in the Republic of Serbia first recorded seropositivity in dogs and domestic poultry (Table 1). The lowest percentage of positive results in domestic poultry is probably due to a shorter life expectancy compared to other species. After epizootiological investigations, it seems that the encephalitis and death in a dog in Central Serbia (Kragujevac) (unpublished data) and in a horse in the region of Čačak is probably due to acute infection of WNV.

Registered cases of seropositivity to WNV in humans in Pec, emphasize that WNV is circulating in the southwestern part of the Republic of Serbia for a long time (1996), which was not the case in 1972 (Bordjoski et al., 1972). Available data indicate that further expansion of WNV through the Republic of Serbia and outbreaks can be expected, as it happened for the first time in 2012 . (Popović et al., 2013).

WNV encephalitis outbreak in humans in Romania, Greece and Serbia in a very short period of time and a lot of confirmed cases, highlighted the problem of diagnosing illness, hospitalization and treatment of a large number of people affected (Cernescu et al., 1997; Papa et al., 2010; Popovic et al., 2012). Serologic investigation, included in the present studies showed that the percentage of positivity was significantly higher when the sera were tested by indirect immunofluorescence assay (IFA) compared to AGID test (unpublished results). With the AGID test the antibodies can be confirmed on the 7th day after infection and last for up to 4 months (Gligic, 1972). Antibodies that can be measured by IFA, ELISA and other methods are present for a long time after the infection, leading to the conclusion that the AGID test results (Tables 1 and 2) confirm recent exposure to the WNV. Therefore, AGID test is a very convenient method for the detection of active foci of WNV infection in humans and animals.

\section{CONCLUSION}

Infection with WNV undoubtedly is actively circulating in the general area of the Republic of Serbia in humans and a number of animal species. The presence of WNV has been shown in 9 out of 18 studied locations in Serbia. Of the 9 species tested the highest seropositivity was registered in horses and the lowest in poultry. In the Republic of Serbia, for the first time, dogs were recognized as a species susceptible to WNV and confirmed as the host for mosquitoes - vectors. In order to track WNV infection in the Republic of Serbia, it is necessary to intensify epizootiological, epidemiological, virological and ecological studies. 


\section{AKNOWLEDGEMENT}

This study was supported by the Ministry of Education, Science and Technological Development Project Grants, TR 21047 and TR 37015

Address for correspondence:

Prof. Bosiljka Đuričić, PhD

Faculty of Veterinary Medicine

University of Belgrade

Bulevar oslobodjenja 18

11000 Belgrade, Serbia

E-mail: bosiljka.djuricic@gmail.com

\section{REFERENCES}

1. Asnis DS, Conetta R, Teixeira AA, Waldman G, Sampson BA, 2000, The West Nile Virus outbreak of 1999 in New York: the Flushing Hospital experience, Clin Infect Dis, 30, 413-8.

2. Bakonyi T, Ivanics E, Erdelyi K, Ursu K, Ferenczi E, Weissenbock H et al. 2006, Lineage 1 and 2 strains of encephalitic West Nile virus, central Europe, Emerg Infect Dis, 12, 618-23.

3. Barzon L, Squarzon L,Cattai M, Franchin E, Paghi S, Cusinato R, et al., 2009, West Nile virus infection in Veneto region, Italy, 2008-2009, EuroSurveill. 14(31):pii=19289.

4. Available online: http://www.eurosurveillance.org/ViewArticle.aspx?Articleld=19289.

5. Bordjoški M, Gligić A, Bošković R, 1972, Arbovirusne infekcije u RS Srbiji, Vojnosanit Pregl, 29, 4, 173-5.

6. Burt FJ, Grobbelaar AA, Leman PA, Anthony FS, Gibson GV, Swanepoel R, 2002, Phylogenetic relationships of southern African West Nile virus isolates, Emerg Infect Dis, 8, 820-6.

7. Campbell GL, Marfin AA,Lanciotti RS, Gubler DJ , 2002, West Nile virus. Lancet. Infect Dis.:2:519-529. DOI: 10.1016/S1473-3099(02)00368-7.

8. Cernescu C, Ruta SM, Tardei G, Grancea C, Moldoveanu L, Spulbar E et al. 1997, A high number of severe neurologic clinical forms during an epidemic of West Nile infection, Rom J Virol, 48, 13-25.

9. Cumakov MP, Rubin A, M, Elbert LB, Pervukov Ju V, 1969, Primenenie polietilenglikolja dlja koncentraciji virusov, Voprosi virusologiji , 6,721- 4.

10. Djuričić B, 2009, Epizootiološka istraživanja na HPI i WNV na lokalitetu Obedska bara preliminarni rezultati, Zbornik radova Kongresa veterinara Srbije, 262-7.

11. Gligić $A, 1972$, Dinamika titrova antitela kod obolelih od velikih boginja, vakcinisanih lica protiv velikih boginja i eksperimentalno inficiranih životinja merena raznim metodama i njihovi međusobni odnosi, Doktorska disertacija, Univerzitet u Beogradu, Madicinski fakultet.

12. Hayes EB, Sejvar JJ, Zaki SR, Lanciotti RS, Bode AV, Campbell GL, 2005, Virology, pathology, and clinical manifestations of West Nile virus disease, Emerg Infect Dis, 11, 1174-9.

13. Hrnjaković Cvjetković I, Cvjetković D Petrić D, Zgomba M, Jerant Patić V et al. 2009, Infekcija virusom Zapadnog Nila: Značaj i dijagnostika, Zbornik radova i kratkih sadržaja Simpozijuma: XI Epizootiološki dani sa međunarodnim učečćem, Apatin, Banja Junaković, 172-4.

14. Krisztalovics K, Ferenczi E, Molnar Z, Csohan A, Ban E, Zoldi V, et al. 2008, West Nile virus infections in Hungary, August-September 2008, Euro Surveill,13 , 45, pii $=19030$.

15. Available online: http:// www.eurosurveillance.org/ViewArticle. aspx?Articleld $=19030$.

16. Kuljić-Kapulica N, Tasić D, Stajkovic N, Krstić M, 2009, Detection of antibodies to West Nile virus (WNV) in human sera, MD Medical data Vol./No2. UDC: 578.833.2 ID=169306636.

17. Lanciotti RS, Roehrig JT, Deubek V, Smit J, Parker M, Steele K, et al. 1999, Origin of the West Nile virus responsible for an outbreak of encephalitis in the northeastern United States, Science, 
18. 286:2333-7.DOI: 10.1126/science.286.5448.2333.

19. Lupulovic D, Miguel A, Martin-Acebes N, Lazic S, Alonso-Padilla J, Belen Blazquez A et al., 2011, First Serological Evidence of West Nile Virus Activity in Horses in Serbia, VectorBorne and zoonotic diseases, Vol.X, Number XX, 2011 Pages: 10-13 DOI: 10.1089/ vbz.2010.0249 http://dx.doi.org/10.1089/vbz.2010.0249.

20. Meister T, Lussy H, Bakonyi T, Šikutova S, Rudolf I, VogI W et al. 2008, Serological evidence of contionuing hihg Usutu virus ( Flaviviridae) activity and establishment of herd immunity in wild birds in Austria, Vet Microbiol, 127, 3-4, 237-48.

21. Nash D, Mostashari F, Fine A, Miller J, O'Leary D, Murray K, et al. 2001, Outbreak of West Nile virus infection, New York City area, 1999, N Engl J Med 344,1807-14.

22. Ouchterlony O, 1949, Antigen-antibody reactions in gels, Acta Path Microb. Scand, 6, 507-15.

23. Ouchterlony O, 1962, Diffusion in gel methods for immunological analysis II, Allergy, 6, 30, 154.

24. Papa A, Danis K, Baka A, Bakas A, Dougas G, Lytras T et al. 2010, Ongoing outbreak of West Nile virus infections in humans in Greece, July - August 2010, Euro Surveill. 2010;15(34):pii=19644. Avalable online: http://www.eurosurveillance.org/ViewArticle. aspx?Articleld $=19644$

25. Platonov AE, Shipulin GA, Shipulina OY, Tyutyunnik EN, Frolochkina TI, Lanciotti RS et al. 2001, Outbreak of west Nile virus infection, Volgograd Region Russia 1999, Emerg Infect Dis, 7, 128-32.

26. Popović N, Milošević B, Urošević A, Poluga J, Lavadinović L, Nedelijković J, Jevtović $D$, Dulović O, 2013, Outbreak of West Nile virus infection among humans in Serbia, August to October 2012. Euro Surveill. 2013;18(43):pii=20613.

27. Smithburn KC, Hughes TP, Burke AW, Paul JH, 1940, A neurotropic virus isolated from the blood of a native of Uganda, Am J Trop Med, 20, 471-92.

\section{SEROEPIZOOTIOLOŠKO-EPIDEMIOLOŠKA ISTRAŽIVANJA I MAPIRANJE INFEKCIJE ZAPADNOG NILA U REPUBLICI SRBIJI}

ĐURIČIĆ BOSILJKA, VASIĆ ANA, ROGOŽARSKI D, VOJINOVIĆ DRAGICA, ELEZOVIĆ RADOVANOVIĆ MILICA, MANIĆ MARIJA, MARIĆ J, PROKIĆ NATASA, ILIĆ ŽIVKA, NOVOTNY N i GLIGIĆ ANA

\section{SADRŽAJ}

Bolest koju izaziva virus Zapadnog Nila (WNV) je poznata još od 1937. kada je po prvi put opisana u Ugandi. Posle širenja virusa u Evropu i na Bliski istok, bolest je promenila prvobitnu lokaciju. Danas je WN infekcija značajan zdravstveni problem u svetu. Kao rezultat trenutne epizootiološko-epidemiološke situacije u Evropi, uvedena su istraživanja prisustva WNV i u Srbiji. Istraživanja prisustva antitela za WNV intenzivirana su u periodu od 2008. do 2012. godine. U ovom periodu ukupno je ispitano 3618 seruma sa 18 lokaliteta (2736 seruma životinja, od 8 različitih vrsta i 882 seruma ljudi). Korišćen je metod imunodifuzije 
u gelu a reprezentativni uzorak potvrđen je testom neutralizacije plaka (PRNT90). Od ukupnog broja uzoraka na prisustvo antitela za WNV bilo je pozitivno $3,97 \%$ konja, 0,93\% pasa, 0,31\% domaće živine i 1,36\% ljudi. U serumu jednog konja pojavila se pozitivna reakcija sa pozitivnim kontrolnim serumom, ukazujući na prisustvo antigena WNV.

Dobijeni rezultati su potvrdili da su antitela za WNV prisutna u 9 od 18 ispitivanih lokacija u Republici Srbiji. Procenat seropozitivnih varira od $0.42 \% \mathrm{u}$ Požarevcu (konji i ljudi) do 6,45\% u Novom Pazaru (psi). Od ispitivanih vrsta najveća seropozitivnost je registrovana kod konja $(3,97 \%)$, a najniža kod živine $(0,31 \%)$. Raspoloživi podaci ukazuju da je WNV prisutan i značajno raširen u Republici Srbiji, što je omogućilo i mapiranje njegovog širenja. 